\title{
Capstone Design in Mechanical Engineering at the University of Western Ontario
}

\author{
Ralph O. Buchal \\ Department of Mechanical \& Materials Engineering \\ The University of Western Ontario \\ London, Ontario, Canada \\ rbuchal@eng.uwo.ca
} \begin{abstract}
parts, materials, prototype construction and testing.
\section{Introduction and Background}

The Canadian Engineering Accreditation Board (CEAB) states that "the engineering curriculum must culminate in a significant design experience which is based on the knowledge and skills acquired in earlier course work and which preferably gives students exposure to the concepts of team work [1]". This paper describes the capstone design course, MME419/499, in the Mechanical Engineering Program at the University of Western Ontario.
\end{abstract}

Abstract

All engineering programs in Canada must culminate in a significant design experience. This paper describes the capstone design course in the Mechanical Engineering Program at the University of Western Ontario. Self-selected student teams choose from several types of projects: faculty-defined projects, student-defined entrepreneurial projects, student design competitions, and industry-sponsored projects. These choices accommodate a wide range of interests and career goals. The primary sources of project funding are industry sponsorship fees and matching funding through the Ontario Centres of Excellence Connections Program. The majority of project expenses are for

\section{Defining “Design"}

The CEAB defines engineering design as follows [1]:

Engineering design integrates mathematics, the basic sciences and complementary studies in developing elements, systems and processes to meet specific needs. It is a creative, iterative and often open-ended process subject to constraints, which may be governed by standards or legislation to varying degrees, depending on the discipline. These constraints may relate to economic, health, safety, social or other pertinent factors.
Design often includes analysis, mathematical modelling, simulation, experimental studies and testing, but those things by themselves do not constitute design. Engineering research or investigative projects are allowable only if they contain significant design content. For example, developing a theoretical model for an engineering phenomenon, and comparing it to experimental results, is not engineering design. To be allowable, such a project might include the design of the experimental apparatus and software. The CEAB states that "a research project may be interpreted as engineering design provided it can be clearly shown that the elements of design, as noted in the definition, are fulfilled in the completion of the project [1]".

\section{Attributes of a Good Design Project}

The CEAB guidelines are very broad, so we have developed more detailed guidelines for MME419/499. We look for projects that exhibit the following attributes of a good design project:

- It should address a "real-world" problem, preferably one of significant importance to society or industry.

- It should involve many sub-problems, and many alternatives solutions. 
- It should be in a relatively unexplored area where the "best" solutions are not widely known or obvious.

- There should be opportunity for innovation and creativity.

- There should be opportunity to incorporate emerging technologies.

- It should be rich in engineering analysis.

- There should be opportunity for prototype construction and testing.

- It should be suitable for CAD/CAM/CAE modelling and analysis.

\section{Elements of Design}

While every project is different, we expect all students to follow an accepted design process consisting of the following generic activities:

1. Identification of need and problem definition.

2. Information gathering and background research.

3. Generation of alternatives.

4. Evaluation of alternatives and selection of the best concepts.

5. Engineering validation.

a. Mathematical modeling and estimation.

b. Computer modeling and simulation.

c. Experimentation and testing.

6. Prototype construction and testing.

7. Preparation of design documentation.

The emphasis on different activities will vary depending on the nature of the project. For a largescale project like designing a new type of vehicle, the emphasis will be on conceptual design, mathematical modeling and estimation. For a fairly simple product design, there may be much more emphasis on prototype construction, testing, detail design documentation, and manufacturing process design.

\section{Project Selection Process}

The majority of projects are done by self-selected teams, but individual projects are permitted on an exception basis. Projects are selected or proposed by student teams. Teams are not assigned projects they did not choose or do not wish to work on. As a result, some projects are not taken, and other projects might have more than one team working on different aspects, or on competing solutions.

\section{Types of Projects}

Students can choose from several types of projects: faculty-defined projects, student design competitions, student-defined entrepreneurial projects, and industrysponsored projects. The breakdown of the number of students and projects of each type for 2006/2007 is shown in Table 1 . Typically about half the students choose to work on industry projects.

Table 1. Breakdown of project types in the 2006/2007 academic year.

\begin{tabular}{|l|l|l|l|}
\hline Project Type & $\begin{array}{l}\text { No. of } \\
\text { Projects }\end{array}$ & $\begin{array}{l}\text { No. of } \\
\text { students }\end{array}$ & $\begin{array}{l}\text { Percent } \\
\text { of } \\
\text { students }\end{array}$ \\
\hline Industry projects & 12 & 44 & $42 \%$ \\
\hline $\begin{array}{l}\text { Faculty-defined } \\
\text { projects }\end{array}$ & 12 & 32 & $31 \%$ \\
\hline Design competitions & 6 & 17 & $17 \%$ \\
\hline $\begin{array}{l}\text { Entrepreneurial } \\
\text { projects }\end{array}$ & 5 & 9 & $9 \%$ \\
\hline Total & 35 & 102 & \\
\hline
\end{tabular}

\section{Faculty defined projects}

Faculty-defined projects typically involve design and construction of experimental apparatus and equipment needed to support faculty research programs. These projects are attractive to students interested in pursuing graduate studies in related research areas.

Faculty members may propose ideas for design projects that are not related to their funded research. An example from 2006/2007 was the design of a guitar-playing robot. 


\section{Entrepreneurial projects}

Entrepreneurial students with innovative and original design ideas are encouraged to define and propose their own design projects. These projects are eligible for funding of up to $\$ 3500$ from the Ontario Centres of Excellence (OCE) Connections Program [2]. Students must submit a business proposal to OCE to be eligible for funding. Student entrepreneurial projects often lead to patents and commercialization opportunities.

\section{Design competitions}

Participation in student design competitions is one of the richest engineering design experiences available to undergraduate students $[3,4]$. Competition teams at Western include Formula SAE, SAE Baja, SAE Aero and Sunstang solar car. Members of these teams are encouraged to propose capstone projects related to the competition. The projects are usually done by existing team members, but projects can also be undertaken by students not previously involved with the team.

The design competition teams typically have a very large budget, and engage in aggressive fundraising to raise the required funds. They receive some funding from the Engineering Student Endowment Fund, and the OCE Connections Program can contribute up to $\$ 2500$ toward these projects.

\section{Industry-sponsored projects}

Finally, students may choose to work on design projects defined by industrial sponsors. Industry sponsored design projects provide students with an opportunity to work with practicing engineers on real industrial problems.

\section{Benefits to Companies}

Sponsorship of student design projects provides many benefits to companies:

- The program offers the potential for a lowcost (no salary expenditures, minimal infrastructure requirements) solution to significant design and manufacturing problems.

- Company representatives are able to interact with potential future employees over an extended period of time in a realistic working environment.
- Faculty expertise and problem-solving skills are provided free-of-charge within the scope of the projects.

- University infrastructure and resources, including machine shop facilities, technical staff, testing labs and instrumentation, computer facilities, meeting rooms, and library resources are made available for the purpose of the student projects.

- The sponsor industry is given the opportunity to explore the different capabilities and services offered by the engineering faculty.

- The feedback from the participating companies is incorporated in the curriculum and helps in the continuous improvement of the program.

- A pathway for technology transfer is established.

- The sponsoring company is granted ownership of any Intellectual Property arising from the project.

\section{Benefits to Students}

Students also benefit from participation in industrysponsored projects. Benefits include:

- The opportunity to work on a real industrial design project.

- Gaining an appreciation of the constraints on time, cost and available resources on real projects.

- Access to funding and resources to permit realistic prototype construction and testing.

- Exposure to professional practice.

- Development of interpersonal and projectmanagement skills.

- Exposure to different engineering working environments and corporate structures.

- Gaining experience interacting with suppliers and clients. 
- Potential employment opportunities with the sponsoring company, or in the related industry.

\section{Organization and management}

Industry projects are administered by the MME419/499 course coordinators. Duties include soliciting projects, developing project descriptions, matching students to projects, managing confidentiality, liaising with sponsors, and matching faculty advisors to projects. Faculty advisors are selected based on their expressed interest in the project, relevant expertise, existing relationships with the company, etc.

\section{Funding and budgets}

The current sponsorship fee is $\$ 3500$ per company. This fee entitles the company to sponsor one or more projects.

Industry sponsorship fees are matched up to $\$ 3500$ through the Ontario Centres of Excellence (OCE) Connections Program. OCE also funds entrepreneurial projects and student design competition teams. Industry and OCE funds are used mainly for purchasing of parts and materials, and construction of prototypes.

\section{Sponsorship agreement and confidentiality}

Sponsoring companies pay a cash participation fee, and enter into a Sponsored Project Agreement (SPA) with the University. The SPA specifies the roles and responsibilities of the University and the Sponsor, handling of confidential and proprietary information, payment of fees, etc. In particular, the agreement assigns any Intellectual Property arising from the project to the sponsor.

Confidentiality of industry projects is protected during the final project presentations by holding closed sessions and requiring those in attendance to sign a non-disclosure agreement. Final reports are withheld from publication without prior approval of the company.

At the conclusion of the project, copies of final reports and all other supporting material (CAD files, etc.) are delivered to the sponsoring company.

\section{Participating Companies}

Participating companies represent all industry sectors. The companies range in size from very small to global. Most projects are with companies or operations located in Southwestern Ontario. Below is a partial list of companies that have sponsored projects over the past several years:

- Adventec Manufacturing

- Armatec

- Borg-Warner Automotive

- $\quad$ Bruce Power

- Braithwood Automation Systems Inc.

- Canada Composting Inc.

- Continental Cork

- Cooper Standard

- Delta Faucet Canada

- Dofasco

- Enerworks Inc.

- Exhaust Direct

- Forest City Velodrome Association

- General Dynamics Land Systems

- General Motors of Canada (Diesel Division)

- Greenway Industries

- HNH Machines

- Holland Equipment Ltd.

- Hudson Boat Works

- Inco Ltd.

- London Beadery

- Long Manufacturing

- Meridian Technologies

- Modus Medical

- Novatronics Inc.

- Purifics Environmental Technologies

- Shred-Tech

- Siemens Electric

- Sparton Electronics Canada Ltd.

- Stackpole Ltd.

- $\quad$ STAXI Corp.

- $\quad$ Sun Valley Foods

- $\quad$ Therm-O-Disc (Canada) Ltd.

- Thomas Hires and Associates Ltd.

- $3 \mathrm{M}$

- Timberjack

- Toyota Motor Company

- Trojan Technologies

- Unifin International Inc.

- Union Gas

- Van-Rob Stampings Inc.

- Wolverine Tube

\section{Sample Industry-Sponsored Projects from Previous} Years

A partial list of industry project titles is shown below: 
- The development of new methods for guiding paper rolls through process ovens.

- Automatic and variable down pressure system for grain planter units.

- $\quad$ Anode casting wheel-drive system.

- $\quad$ Product labeling process.

- Development of a suspended tow dolly.

- Automatic train-line tester.

- $\quad$ Redesigning an engine/generator alignment procedure.

- $\quad$ Theoretical modeling of a magnesium melt furnace.

- Multi-pass spur gear head design.

- Quality control testing procedure for use in the production of temperature switches.

- Design of a small-scale wind turbine.

- $\quad$ Testing and evaluation of expansion loops and saddle reinforcements for branch connections.

- Design of an improved rigger for competitive rowing shells.

- Design of an improved transportation system for automotive parts shipping.

- Design of a mine blast simulation device.

- Design and optimization of an aluminum smelting process utilizing a rotary furnace.

- Design of a corrosion-resistant magnesium structural cross-member for exterior automotive applications.

- Design of an aluminum membrane wash station.

- Conceptual design of next-generation mobile air conditioning systems for future armored vehicles.
- Design of a wing-cut machine for chicken processing.

- $\quad$ Fin and steering design for a rowing racing shell.

- Innovative applications of magnesium in sporting equipment.

- Design of a Rivnut removal system.

- Redesign of flexible exhaust pipes to reduce failures.

\section{6/2007 Industry-sponsored Projects}

In the 2006/2007 academic year, there were twelve projects sponsored by nine companies or organizations. The companies and projects are listed in this section.

EnerWorks Inc. (Dorchester, Ontario)

- Improved manufacturing methods and materials for solar collector insulation

- Solar Collector Stagnation Device Redesign

- Design of Solar collector mounting system

Forest City Velodrome Association (London, Ontario)

- Design of a Bicycle Starting Gate

General Dynamics Land Systems - Canada (London, Ontario)

- Investigate alternative approaches for handling Armored Hulls and Chassis during Manufacturing and Assembly of Light Armoured Vehicles (LAVs)

- Parametric study of fuel cell power for auxiliary loads on a Light Armoured Vehicle.

Holland Equipment Ltd. (Norwich, Ontario)

- Innovative design of cargo lifting system for semi-trailers

London Beadery (London, Ontario)

- $\quad$ Design of bead Sorting and repackaging equipment

Meridian Technologies (Strathroy, Ontario)

- Development of a new coating process for magnesium automotive components 
Shred-Tech (Cambridge, Ontario)

- STS-75 Single Rotor Shredder Analysis and Design

Stackpole Ltd. (Mississauga, Ontario)

- New Hopper Design to Prevent Segregation of Metallic Powders

Sun Valley Foods (London, Ontario)

- Design of Crate Moving System

\section{Summary of Funded Projects}

The number of students participating in industrysponsored projects has increased significantly since $2004 / 2005$, and appears to have leveled off at about half of the total $4^{\text {th }}$-year class. The rest of the class prefers to select a non-industry project. Ten to fifteen industry projects per year are required to meet student demand.

Student entrepreneurs are encouraged to propose their own projects, and apply for OCE Connections funding. Three entrepreneurial projects have received OCE funding in the past three years.

Table 2 shows a breakdown of the funded industrial and entrepreneurial projects over the past three years.

Table 2. Project statistics for past three academic years.

\begin{tabular}{|l|l|l|l|}
\hline & $2004 / 05$ & $2005 / 06$ & $2006 / 07$ \\
\hline Total Projects & 29 & 34 & 37 \\
\hline Total students & 94 & 97 & 102 \\
\hline $\begin{array}{l}\text { Sponsoring } \\
\text { companies }\end{array}$ & 6 & 8 & 9 \\
\hline Sponsored projects & 6 & 11 & 12 \\
\hline Sponsored students & 23 & 39 & 44 \\
\hline $\begin{array}{l}\text { Entrepreneurial } \\
\text { projects }\end{array}$ & 0 & 1 & 2 \\
\hline $\begin{array}{l}\text { Entrepreneurial } \\
\text { students }\end{array}$ & 0 & 3 & 6 \\
\hline
\end{tabular}

In addition to providing matching funding for industry projects, OCE Connections also provides funding for entrepreneurial projects and student design competition projects (SAE car teams). Table 3 shows a summary of project funding over the past three academic years. Total industry cash decreased in 2006/2007 because we reduced the sponsorship from $\$ 5000$ to $\$ 3500$. The steady-state total is about $\$ 60 \mathrm{~K}$.

Table 3. Summary of project funding for past three academic years.

\begin{tabular}{|l|l|l|l|}
\hline & $2004 / 05$ & $2005 / 06$ & $2006 / 07$ \\
\hline Total industry cash & $\$ 30,000$ & $\$ 35,000$ & $\$ 25,500$ \\
\hline $\begin{array}{l}\text { OCE Connections } \\
\text { matching amount }\end{array}$ & $\$ 21,000$ & $\$ 24,000$ & $\$ 25,500$ \\
\hline $\begin{array}{l}\text { OCE Connections } \\
\text { amount for } \\
\text { entrepreneurial nil } \\
\text { projects for SAE }\end{array}$ & nil & $\$ 2500$ & $\$ 2500$ \\
\hline $\begin{array}{l}\text { OCE Connections } \\
\text { amount for } \\
\text { teams }\end{array}$ & $\$ 51,000$ & $\$ 65,000$ & $\$ 60,500$ \\
\hline \begin{tabular}{l} 
Total cash \\
\hline
\end{tabular}
\end{tabular}

\section{Resources}

Students have access to a full suite of CAD/CAM/CAE software including SolidWorks and NX. There is a basic student workshop for prototype construction. In addition, professional prototyping services are available through a partnership with University Machine Services (UMS). These services include rapid prototyping using $\mathrm{FDM}$ and $3-\mathrm{D}$ printing technologies [5]. A significant portion of the project funding is used for UMS prototyping services.

\section{Milestones, Deliverables and Evaluation}

Design teams meet regularly with their faculty and industry advisors throughout the project. Students are required to deliver a written proposal, progress reports, a final design report, and a final presentation. These are evaluated based on several criteria, including: problem definition, background research and innovation, use of proper design methodology, appropriate engineering 
validation based on mathematical modeling, computer simulation and prototype testing, quality and completeness of design documentation, and technical writing.

\section{Conclusions}

The capstone design course in the Mechanical Engineering Program at the University of Western Ontario provides students with a choice of design experiences, to accommodate different career goals. Consistent design methodology and deliverables are used, with flexibility to accommodate differences between projects. Industry and matching Ontario Centres of Excellence funding is used to support the project costs.

Since students choose their own teams and projects, their motivation and interest are high resulting in excellent outcomes.

\section{References}

[1] Accreditation Criteria and Procedures, Canadian Engineering Accreditation Board, Canadian Council of Professional Engineers, 2006.

[2] Ontario Centres of Excellence Connections Program, http://www.oce-ontario.org/, accessed June 14, 2007.

[3] Buchal, R. O., “The Educational Value of Student Design Competitions", Proceedings of The Inaugural CDEN Design Conference, Montreal, July 2004.

[4] Buchal, R. O., Atcha, I.; Da Rocha, A.; Jelenik, R.;

Kriznic, P.; "Student Design Teams at UWO: a Case Study", Proceedings of the Second CDEN International Conference on Design Education, Innovation, and Practice, Kananaskis, Alberta, July 2005

[5] Buchal, R. O., Phillips, D., The Use of Rapid Prototyping in Undergraduate Design Education, The $3^{\text {rd }}$ CDEN/RCCI

International Design Conference, Kananaskis, Alberta, July 24-26, 2006 